\title{
The Facebook and NGO's Accountability Practices
}

\section{Noor Muafiza Masdar, Rohaida Basiruddin, Yunita Fitria}

To Link this Article: http://dx.doi.org/10.6007/IJARAFMS/v12-i1/11974 DOI:10.6007/IJARAFMS /v12-i1/11974

Received: 18 November 2021, Revised: 21 December 2021, Accepted: 29 December 2021

Published Online: 19 January 2022

In-Text Citation: (Masdar et al., 2022)

To Cite this Article: Masdar, N. M., Basiruddin, R., \& Fitria, Y. (2022). The Facebook and NGO's Accountability Practices. International Journal of Academic Research in Accounting Finance and Management Sciences, 12(1), 166-173.

\section{Copyright: @ 2022 The Author(s)}

Published by Human Resource Management Academic Research Society (www.hrmars.com)

This article is published under the Creative Commons Attribution (CC BY 4.0) license. Anyone may reproduce, distribute, translate and create derivative works of this article (for both commercial and non-commercial purposes), subject to full attribution to the original publication and authors. The full terms of this license may be seen at: http://creativecommons.org/licences/by/4.0/legalcode

Vol. 12, No. 1, 2022, Pg. 166 - 173

Full Terms \& Conditions of access and use can be found at http://hrmars.com/index.php/pages/detail/publication-ethics 


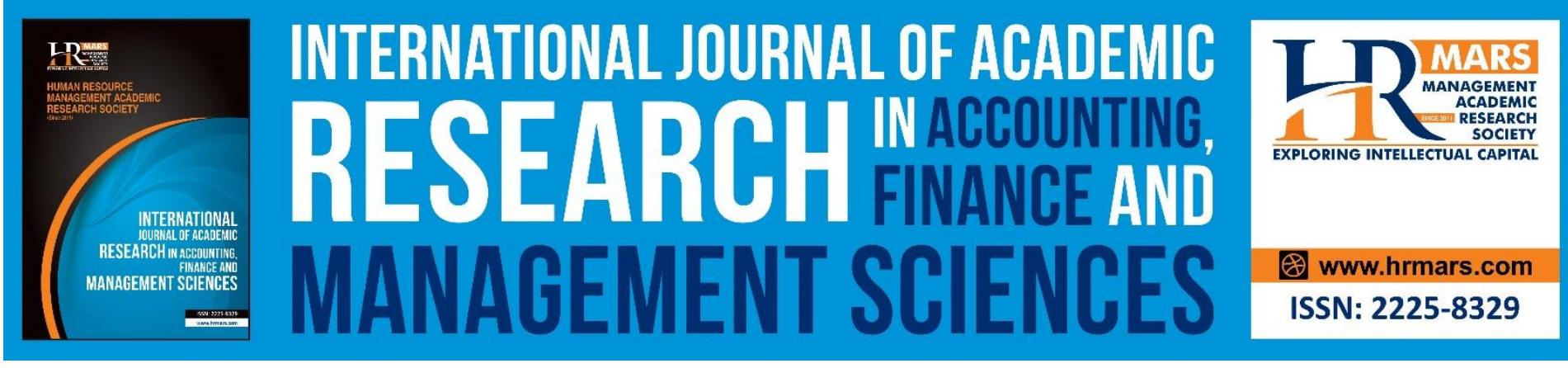

\title{
The Facebook and NGO's Accountability Practices
}

\author{
Noor Muafiza Masdar ${ }^{1}$, Rohaida Basiruddin², and Yunita Fitria ${ }^{3}$ \\ ${ }^{1}$ Azman Hashim International Business School, Universiti Teknologi Malaysia, Jalan Sultan \\ Yahya Petra, 54100, Federal Territory of Kuala Lumpur, Malaysia; and Labuan Faculty of \\ International Finance, Universiti Malaysia Sabah, Jalan Sungai Pagar, 87000, Federal \\ Territory of Labuan, Malaysia, ${ }^{2}$ Azman Hashim International Business School, Universiti \\ Teknologi Malaysia, Jalan Sultan Yahya Petra, 54100, Federal Territory of Kuala Lumpur, \\ Malaysia, ${ }^{3}$ Fakultas Ekonomi and Bisnis, Universitas Mulawarman, Jl. Kuaro, Gn. Kelua, Kec. \\ Samarinda Ulu, Kota Samarinda, Kalimantan Timur, 75119, Indonesia. \\ Email:muafiza@ums.edu.my,rohaida.kl@utm.edu.my,yunita.fitria@feb.unmul.ac.id
}

\begin{abstract}
Nowadays, the famous platform to share information is through social media such as Facebook. Unlike other sectors that provide written documents in attracting their investors, a situation in the third world sector seems different. Facebook becomes a familiar platform for a non-government organization (NGO) to share information about their activities including fundraising. Facebook allows NGOs to communicate with potential and existing donors. However, Facebook also has the potential to destroy the NGOs themselves through inaccurate information shared by the user of social media. This situation could create harm to the NGOs' reputation if they are not taking proactive action. This study investigates how far Facebook can express the NGO's accountability practices. This study uses a qualitative approach by choosing NGO in Malaysia as a case study. This NGO has humanitarian aid towards refugees especially in the middle east countries. Data was collected through document analysis and interviews with ten (10) interviewees including NGO personnel, donors, and beneficiaries. Underlying to social capital theory, this research found Facebook has a powerful impact on the NGO's accountability practices. The Facebook application becomes a norm for NGOs to express their activities. It allows NGOs to convince donors for fundraising purposes. Therefore, this study found Facebook has a vulnerability towards accountability practices in the NGO. The limitation of the study only focuses on Facebook as social media accountability. Thus, the comparision of NGO disclosure between other social media could be applied in the next future study.
\end{abstract}

Keywords: Accountability, Beneficiaries, Donors, Facebook, NGO.

\section{Introduction}

Nowadays, social media is a very essential part of the organization. Social media can give a great effect on society in terms of social responsibility. According to (Kaplan \& Haenlein, 2010), social media can be an identity of organizations. It can be said that social media becomes a tool to explore accountability practices. Social media aim to provide information to the stakeholder (Bellucci \& Manetti, 2017; Manetti \& Bellucci, 2016). Therefore, a non- 
MANAGEMENT SCIENCES

Vol. 12, No. 1, 2022, E-ISSN: 2225-8329 @ 2022 HRMARS

government organization (NGO) is one of the organizations which publish their activities on social media. Social media becomes a prominent factor in delivering accountability practices. Accountability is an individual action in doing the tasks. Dhanani and Connolly (2014) explained accountability is a bind of several obligations that managers want to choose and to do in the organization.

The digital era has brought many benefits to many sectors including non-government organizations (NGOs). This third world sector existed with a mission to assist those in need and to justify the human rights of people. The NGOs work closely related to the community, and they are gaining many benefits from information shared on social media such as Facebook. Facebook is a prominent social media that has been introduced by Mark Zuckerberg and it has been established since the year 2004. Unlike other sectors, NGOs utilize the usage of Facebook at an optimum level in exposing their activities, raising funds, and telling the world about the humanitarian aid that they are involved in. During the covid-19 pandemic, NGOs received many benefits from Facebook. They can work anywhere and share their information with the world in a very short time. They can raise funds through their Facebook posting. The problem came across in the way in which information shared by the NGO on Facebook can attract donors to donate, where trust is developed between donors to the NGO. However, trust is fragile and requires consistent commitment from the NGO to manage it. Inaccurate information shared with the stakeholders might destroy the NGO in terms of the failure of funding and trust from its stakeholders. Pertaining to this issue, this study intends to investigate the way in which Facebook becomes a platform for NGO's accountability practices.

\section{Literature Review Social Media}

Social media is treated as an organizational tool for showing their performance in society. Social media can be defined as an online platform that shows several organizational activities for accountability and performance (Amelia \& Dewi, 2021; Bellucci \& Manetti, 2017; Manetti et al., 2016). Their accountability and performance are an important part of the organization, in addition, they can be the identity of an organization (Kaplan \& Haenlein, 2010). There are several studies about the effect and the usage of social media (Amelia \& Dewi, 2021; Fu \& Zhang, 2019; Manetti \& Bellucci, 2016; Susan et al., 2012; Zhou \& Pan, 2016).

Manetti and Bellucci (2016) explained social media can be essential to make interactive communication between the organization and stakeholder. It means that the stakeholder will communicate through seeing the social media posting on the website. The post of social media maintains the organization's existence (Amelia \& Dewi, 2021). Susan et al (2012) explained that the interesting social media features always show the review of the organization's activities. The review should consist of the activities that organizations do for society. It will increase the performance from the social perspective. Besides the performance, social media can filter the socio and political problems in an organization's dilemmas (Fu \& Zhang, 2019). Thus, organizations can show the reality of their practices in terms of non-governmental organizations.

However, organizations should take attention to using media in terms of facing challenges. (Kaplan \& Haenlein, 2010) mentioned two points of suggestion namely using media and being social. Using media means the organization must decide the tool carefully, buy or make, ensure the activity, choose a plan, and open access. Being social also has several points, namely being active, being interesting, being humble, being unprofessional, and being 
MANAGEMENT SCIENCES

Vol. 12, No. 1, 2022, E-ISSN: 2225-8329 @ 2022 HRMARS

honest. Those pieces of advice will be beneficial for the organization in maintaining its responsibility and performance. The next section will provide information about accountability in NGOs.

\section{Accountability in NGOs}

Accountability is an act of an individual to do all of their obligations. Accountability means giving accountable action to upward and downward (Dwyer \& Unerman, 2008). They focused on holistic accountability in giving the action. Ebrahim (2003) stated accountability is not only related to behavior but also reporting statements in the practices. Thus, the action of the organization in giving accountability should be disclosed in the report.

There are several studies about NGOs' accountability (Bellucci and Manetti, 2017; Fu and Zhang, 2019; Goncharenko, 2021; Neu et al., 2020; Smitko, 2012; Yates et al., 2019). Accountability can be also defined as socializing and intelligent accountability which means that organizations must have a good relationship between internal and external organizations such as managers and donors (Yates et al., 2019). The communication between internal and external parts of the organization will maintain the existence of organizations. However, if there is bad news from the NGOs related to the performance, it will ruin the quality of the organization (Goncharenko, 2021). Therefore, NGOs must be careful in delivering their activities on social media (Bellucci \& Manetti, 2017). Indeed, social media becomes an alternative way in delivering NGOs' accountability such as Twitter (Neu et al., 2020; Smitko, 2012), Facebook (Bellucci \& Manetti, 2017), and youtube (Manetti \& Bellucci, 2016).

\section{Social Capital Theory}

This social capital theory has been widely used in the sociology field. The value of social capital constitutes the structure of its position in actor or organization (Coleman, 1988). This means that the theory focuses on the character of the actor or organization. There are 3 parts of social capital theory namely, trust, information, and norms. According to (Watson \& Papamarcos, 2002), Coleman's theory more focuses on an interpersonal character from an actor or organization. He claimed that social capital theory included quantity and quality in their structure. The quality can be seen from trust and norms, then information can be calculated as quantity part of social capital theory. Trust is an essential part of relationships between humans and organizations (Coleman, 1988). Trust collects the donor's belief in the organizations' activities. Coleman's theory also enforces norms as part of the human or organizational character (Campbell, 2014). Therefore, quality parts of the social capital theory are very pivotal to support the NGO's accountability.

\section{Research Methodology}

This research is using a case study approach at a specific NGO due to gaining a deep understanding from different personnel of the organization. The data collection technique of this study is a semi-structured interview, observation, and document analysis. The semistructured interview has been done with then (10) informants including NGO personnel, donors, and beneficiaries. This study has chosen to interview multi-level personnel of the NGO because the accountability practices should come from every person. Ultimately, individual accountability will shape the accountability practices in the organization.

In strengthening the interview, observation takes place by joining the NGO's meeting with all employees including the CEO. The broad discussion has been through, and Facebook becomes the main issue that arose during the meeting. This observation has given the 
MANAGEMENT SCIENCES

Vol. 12, No. 1, 2022, E-ISSN: 2225-8329 @ 2022 HRMARS

researcher a broad view of the impact of social media on the NGO. Not limited to this, the researcher also did their document analysis with online documents and published documents during the meeting.

All data collected from the semi-structured interview, observation, and document analysis then be triangulated. Triangulation allows the researcher to have a deep understanding of the NGO from a different perspective of data collection techniques. The data then be scrutinized by using NVivo 12 software for coding management and been analyzed by using thematic analysis until it reaches saturation and finding.

\section{Findings and Discussion}

This study found the information shared by the NGO could be in written and in picture form in convincing the stakeholders. Facebook has given many opportunities for NGOs to ease their work especially when they want to communicate with the stakeholder groups.

"We normally put our pictures of projects on our Facebook page ... Normally, this method is successful especially for individual donors ... Our practice is flexible depending on the availability and understandability of people" (Personnel C, 2021).

"We do not rely on one single method only to share with people. We divert to another available platform... We do anything that we can as long as the information is delivered to the public" (Personnel A, 2021).

The NGO found Facebook platform enable them to publish the development of their projects to their stakeholders. In addition, NGOs also being active to find out other ways to share information with the world. This alternative has remained on standby if only they stuck in the Facebook application. Other than publishing projects on Facebook, NGOs also receive feedback from their project's development through Facebook messenger. It shows that the Facebook platform plays a crucial role in NGOs' activities. It assists NGOs from many aspects started from raising the fund to the feedback from stakeholders.

"We receive a lot of messages through our Facebook messenger ... We got feedback from beneficiaries ... We will make improvements for the next project" (Personnel B, 2021).

The stakeholder's feedback is crucially important for NGO's survival. The feedback will determine how far NGO can maneuver its organization. The benefits received by Facebook are not taken easily by the NGO. In other situations, they have to face some difficulties from the system developer.

"Our Facebook in headquarters has been totally blocked by the system. But that's ok. We can use other platform as a second option" (Personnel D, 2021).

The non-government organization always be prepared for any circumstances that might happen in the future and currently happening to them. For this purpose, they are preparing another platform as a second option. 
"As a donor, I am very particular about projects development of the NGO that I donate ... Normally I will do my own research before I transfer money to them ... I will go through the NGOs' social media and their websites" (Donor, 2021).

The donor also clarified that he received information about the NGO through social media which is Facebook. It's a common platform for many people around the globe. That's become a strong reason for the establishment of the NGO being influenced by the Facebook application. Facebook becomes the identification of NGOs' practices (Bellucci \& Manetti, 2017; Pavlovic et al., 2014). Therefore, NGOs should be careful in delivering their activities on social media.

\section{The Vulnerability of Facebook is Embedded in Representing the NGO's Accountability Practices}

The NGOs' accountability practices have a strong connection with Facebook usage. The accountability practices of the NGO remains absence without the application of facebook. Many NGOs have applied Facebook as a medium for them to communicate with their stakeholders. The question comes across whether this Facebook give a strong influence on them or not still be questioned for many academia. For this case study, the application of the Facebook platform is highly influenced by the NGO's activities. It has been started from the NGO's posting to raise funds, to tell the world about the NGO's activities, until feedback from the NGO's stakeholders. The studied NGOs have been found the Facebook platform is applicable and give a big influence on their NGO. However, other NGOs in different places and different countries might experience different platforms to be useful for them such as Twitter (Manetti et al., 2016; Neu et al., 2020; Smitko, 2012), youtube (Manetti \& Bellucci, 2016).

The Facebook application that could retrieve all the memories from the whole year and before making this platform becomes favorable for the studied NGO. This is because the chronological of the NGO's projects development can be seen through the Facebook timeline. This is important in attracting more donors to donate to the NGO's projects. Trust can be developed through the history of this project from the Facebook application. Unlike this NGO, other NGOs claimed Facebook history could harm themselves especially from negative comments of facebook's users (Pavlovic et al., 2014). It is a non-favorable platform for other NGOs (Bellucci \& Manetti, 2017).

In addition, some NGOs heavily rely on other social media platforms such as Instagram because it allows NGOs to attract the young generation to understand the humanitarian issue and shape their behavior of helping people.

Underlying the social capital theory, this studied NGO found the information shared on Facebook can attract stakeholders' trust in raising the fund for the project's development. Also, the information shared in social media like Facebook becomes a norm for the NGO to practice that behavior.

Therefore, the existence of the Facebook platform is vulnerable in expressing the accountability practices by the NGO. Even though many social media platforms are being introduced nowadays, however, Facebook becomes the most favorable platform for this studied NGO in attracting more donors and expressing the NGO's accountability. 
MANAGEMENT SCIENCES

Vol. 12 , No. 1, 2022, E-ISSN: 2225-8329 @ 2022 HRMARS

\section{Conclusion}

The existence of NGOs is influenced by the humanitarian issue, and they are existing for assisting the public as well. Thus, the way in which NGOs would like to communicate to their stakeholder also must be a platform that is widely used by the public. Due to this matter, Facebook is a social media platform that has been used widely by many people all over the world and it's become the most favorable platform for NGOs as well. The studied NGO takes this social media opportunity in expressing their activities and projects development. Not limited to this, the Facebook platform is also able to assist NGOs in raising funds. Indirectly, these practices allow NGOs to perform their accountability to their stakeholders, especially for donors. Based on the social capital theory with elements of norms, information, and trust, this studied NGO is able to communicate with their stakeholders by looking at the rising number of funds collected year by year. However, this study only collected data from one NGO in Malaysia. This study will become more interesting if robust data can be collected from various NGOs based on their specific humanitarian projects. From here, it could be the application from various social media able to express accountability practices from different angles and perspectives.

\section{References}

Abouassi, K., \& Trent, D. L. (2016). NGO Accountability From An NGO Perspective : Perceptions , Strategies, and Practices. 296, 283-296. https://doi.org/10.1002/pad

Amelia, S. R., \& Dewi, M. K. (2021). How a nonprofit organization delivers online accountability through social media.

Ana-maria, G., Frank, E., \& Cornelia, S. M. (n.d.). The Trust Premium : How NGO 's in Romania Adopt International Standards for Accountability, Transparency and Effectiveness. 5360.

Bellucci, M., \& Manetti, G. (2017). Facebook as a tool for supporting dialogic accounting ? Evidence from large philanthropic foundations in the United States. Accounting, Auditing \& Accountability Journal, 30(4), 874-905. https://doi.org/10.1108/AAAJ-072015-2122

Campbell, D. E. (2014). Social Capital and Service Learning. 33(3), 641-645.

Coleman, J. S. (1988). Social Capital in the Creation of Human Capital. The American Journal of Sociology, 94, S95-S120.

Dhanani, A., \& Connolly, C. (2014). Non-governmental Organizational Accountability : Talking the Talk and Walking the Walk ? https://doi.org/10.1007/s10551-014-2172-1

Dwyer, B. O., \& Unerman, J. (2008). The paradox of greater NGO accountability : A case study of Amnesty Ireland. Accounting, Organizations and Society, 33(7-8), 801-824. https://doi.org/10.1016/j.aos.2008.02.002

Ebrahim, A. (2003). Accountability In Practice: Mechanisms for NGOs. 31(5), 813-829. https://doi.org/10.1016/S0305-750X(03)00014-7

Fu, J. S., \& Zhang, R. (2019). NGOs' HIV / AIDS Discourse on Social Media and Websites: Technology Affordances and Strategic Communication Across Media Platforms. 13, 181-205.

Goncharenko, G. (2021). Critical Perspectives on Accounting In the spotlight : Rethinking NGO accountability in the \# MeToo era. Critical Perspectives on Accounting, xxxx, 102308. https://doi.org/10.1016/j.cpa.2021.102308

Kaplan, A. M., \& Haenlein, M. (2010). Users of the world, unite! The challenges and opportunities of Social Media. https://doi.org/10.1016/j.bushor.2009.09.003 
MANAGEMENT SCIENCES

Vol. 12, No. 1, 2022, E-ISSN: 2225-8329 ๔ 2022 HRMARS

Manetti, G., \& Bellucci, M. (2016). The use of social media for engaging stakeholders in sustainability reporting. Accounting, Auditing \& Accountability Journal, 29(6), 9851011. https://doi.org/10.1108/AAAJ-08-2014-1797

Manetti, G., Bellucci, M., \& Bagnoli, L. (2016). Stakeholder Engagement and Public Information Through Social Media: A Study of Canadian and American Public Transportation Agencies. https://doi.org/10.1177/0275074016649260

Neu, D., Neu, D., Saxton, G., Rahaman, A., \& Everett, J. (2020). Twitter and social accountability: Reactions to the Panama Papers Critical Perspectives on Accounting Twitter and social accountability : Reactions to the Panama Papers. Critical Perspectives on Accounting, 61(April 2019), 38-53. https://doi.org/10.1016/j.cpa.2019.04.003

Pavlovic, J., Lalic, D., Djuraskovic, D., Vsdfh, U., Dqg, W., Eh, F. D. Q., Fkdqqho, D. U., Pruh, I. R. U., Wkdq, F., Wuhqg, L. Q., Iru, V., Lvvxhv, F., Kdv, D. Q. J., Wkh, F., Iru, S., Lq, L., Qxpehu, W. K. H., Dwlrqv, R., Wr, E., ... Ri, E. H. (2014). Communication of NonGovernmental Organizations via Facebook Social Network. 25(2), 186-193.

Smitko, K. (2012). Donor engagement through Twitter. Public Relations Review, 38(4), 633635. https://doi.org/10.1016/j.pubrev.2012.05.012

Susan, V., License, C. C. A., Published, A., \& Terms, D. (2012). Materialization of social media in the travel sector. 0-38.

Watson, G. W., \& Papamarcos, S. D. (2002). Social Capital and Organizational Commitment. 16(4), 537-552.

Yates, D., Gebreiter, F., Lowe, A., \& Yates, D. (2019). The internal accountability dynamic of UK service clubs: towards ( more) intelligent accountability? The internal accountability dynamic of UK service clubs : towards ( more ) intelligent accountability ? Accounting Forum, 43(1), 161-192. https://doi.org/10.1080/01559982.2019.1589907

Zhou, H., \& Pan, Q. (2016). Information, Community, and Action on Sina-Weibo : VOLUNTAS: International Journal of Voluntary and Nonprofit Organizations. https://doi.org/10.1007/s11266-016-9685-4 